\title{
The Roles of Islamic Education in Building Students' Character within Indonesia Public Schools
}

\author{
Darlan Darlan ${ }^{1 *}$ Sagaf S. Pettalongi ${ }^{2}$, and Rustina Rustina ${ }^{3}$ \\ ${ }^{1}$ Islamic Education Department, Postgraduate, Institut Agama Islam Negeri Palu \\ 2 Islamic Education Department, Postgraduate, Institut Agama Islam Negeri Palu \\ ${ }^{3}$ Islamic Education Department, Postgraduate, Institut Agama Islam Negeri Palu
}

\section{ABSTRACT}

This study examined the role of Islamic education in building students' character within Indonesia public schools. In conducting the study, we used a qualitative case study method. The case of this study was a state senior high school in Palu city. Data were gathered through direct field observation, in-depth interviews which involve teachers and students. We also analyzed written material, such as the school curriculum, to understand how the character building strategies were integrated in the curriculum. Iur study found that teachers implement character building strategies through several stages, namely the stages of planning, the stages of learning implementation, and the stages of evaluating Islamic religious education learning. The characters values were embedded in the learning of Islamic religious education. This included the integration of character values in the school curriculum and they were taught in every day classroom leanings and in extracurricular activities.
ARTICLE

INFORMATION

\section{Keywords:}

Islamic education, Islamic values, students character, character building 


\section{Introduction}

Character education can be interpreted as a value-based education, or moral education which aims to develop the ability of students to realize the goodness in everyday life. Character education can also be understood as an education system that embeded character values to school members. ${ }^{1}$ This includes components of knowledge, awareness or willingness, and actions to implement these values. ${ }^{2}$ As such, implementing character education in schools all components must be involved, including the components of education itself, namely curriculum content, learning and assessment processes, handling or managing subjects, school management, implementation of co-curricular activities or activities, empowerment of infrastructure, financing, and work ethic for all school members.

Character education can be interpreted as value education, character education, moral education, character education which aims to develop the ability of students to realize the goodness in everyday life wholeheartedly, a system of inculcating

1 Askar, Askar, Adawiyah, Adawiyah, \& Nurdin, Nurdin. (2021). Understanding Students' Psychological Distress Complaints through Online Academic Advising Support. Medico Legal Update, 21(3), 162-167.

2 Rusli, Rusli, \& Nurdin, Nurdin. (2021). Understanding Indonesia millennia Ulama online knowledge acquisition and use in daily fatwa making habits. Education and Information Technologies. doi: 10.1007/s10639-02110779-7 character values to school members which include components of knowledge, awareness or willingness, and actions to implement these values. ${ }^{3}$ So that in character education in schools, all components (educational stakeholders) must be involved, including the components of education itself, namely curriculum content, learning and assessment processes, handling or managing subjects, school management, implementation of cocurricular activities or activities, empowerment of infrastructure, financing, and work ethic for all school members.

The main goal in the concept of character education, moral education, or moral education here is to shape children's personalities so that they become good human beings. Real humans who have not only intellectual intelligence (IQ) but also have emotional intelligence (EQ) and spiritual intelligence (SQ), whether he is a citizen of the school, a citizen of the community, and also a good citizen so that justice and happiness can be achieved. The criteria for good human beings, good citizens, and good citizens for a society or nation, in general, are certain social values, which are heavily influenced by the culture of the community and nation. 4

3 Amiruddin, Amiruddin, Nurdin, Nurdin, \& Ali, Moh. (2021). Islamic Education Teacher Communication Strategy in Increasing Students' Learning Interest. International Journal of Contemporary Islamic Education, 3(1), 41-61.

${ }^{4}$ Rusli, Rusli. (2014). Teaching Usul alFiqh: A Multicultural Education Model. AlTahrir: Jurnal Pemikiran Islam, 14(2), 447-464.

e-ISSN: 2715-4572

p-ISSN: 2716-1439 
The values of the nation's character based on an empirical study of the Curriculum Center of the Research and Development Agency of the Ministry of National Education are; 1) religious, 2) honest, 3) tolerance, 4) discipline, 5) hard work, 6) creative, 7) independent, 8) democratic, 9) curiosity, 10) national spirit, 11) patriotism, 12) appreciate achievements,

friendly/communicative, 14) love peace, 15) love to read, 16) care for the environment, 17) care about social, 18) responsibility. ${ }^{5}$

The nature of character education in the context of education in Indonesia can be interpreted as value education, namely education of noble values originating from the culture of the Indonesian nation itself, in order to foster the personality of the younger generation. Strengthening moral education or character education legally formal in the national education system is actually not a new thing anymore, because character building has become one of the goals of national education, where the 2013 curriculum states that among the goals of national education is to develop the potential of students to become human beings who believe and fear God Almighty, have a noble character, are healthy, knowledgeable, capable, creative, independent and become democratic and responsible citizens.

5 Kementerian Pendidikan Nasional, Pedoman Pelaksanaan Pendidikan karakter. (Jakarta: Pusat Kurikulum dan pembukuan Badan Penelitian dan Pengembangan Kementerian Pendidikan Nasional, 2011), 5.
Legally and formally, character building is the main goal, but in the social reality of education, it turns out to show the fragility of the existing out-put and out-come characters. Therefore, in the current context, character education is very relevant to overcoming the moral crisis currently engulfing Indonesia. These crises include increasing promiscuity, rampant rates of violence and crime against friends, theft by teenagers, cheating habits, drug abuse, pornography, and the destruction of other people's property which has become a social problem that until now has not been completely resolved. as well as the rampant corruption practices carried out by state apparatus officials, both those who sit in the executive or legislative institutions as well as other high state institutions.

The 2013 curriculum emphasizes the assessment of attitudes, knowledge, and skills. This curriculum is also called the character-building curriculum because attitude is the most important assessment before assessing the two things after that. In the 2013 curriculum, attitudes are contained in Core Competencies (KI) one to four and in Basic Competencies (KD) one and two. New knowledge starts at KD three and skills at KD four. In the 2013 curriculum, processes and results are important.

Nothing is more superior. It is hoped that this curriculum will create more competent, productive, and creative individuals. So that teachers are required not only to teach but to instill concepts and characters into students significantly. Teacher creativity is an important factor in implementing the

e-ISSN: 2715-4572

p-ISSN: 2716-1439 
2013 curriculum. This curriculum has a scientific approach that emphasizes more on learning that activates students. The learning process is likened to the teacher only planning by making a scenario, and then the teacher becomes the director. Only the students play a role according to the predetermined characters. So that students will have direct experience, and the concept becomes the basis for forming the character of their mindset.

The 2013 curriculum is a core part of Strengthening Character Education. Therefore, the 2013 Curriculum technical guidance module is integrated with approaches in Strengthening Character Education. This integration is needed so that there is no confusion among teachers about the existence of the 2013 Curriculum and KDP or other programs that are a support system for the development of school quality, such as the school literacy movement, Adi Wiyata schools, and others.

The formation of attitudes, moral and personal development in general, occurs through experience from childhood. The first educators or coaches are parents, then teachers. All the experiences that the child goes through as a child will be an important element in his personality. The student's attitude towards religion is first formed at home through the experiences he gets with his parents, then refined or improved by the teacher at school. The condition of the community environment is so vulnerable to the growth of aggressive and deviant behavior among students. Therefore, efforts to educate students who emphasize intellectually need to be balanced with character building, which is also included in the material that must be taught, mastered, and realized by students in everyday life.

Islamic religious education provides knowledge and shapes students' attitudes, personality, and skills in practicing their religious teachings, which is carried out at least through subjects at all lines, levels, and types of education. Philosophically, Curriculum 2013 develops the individual lives of students in religion, art, creativity, communication, values from various dimensions of intelligence that are suitable for a student and needed by society, nation, and humankind. So that religious education here plays a vital role in curriculum implementation. In the 2013 curriculum concept, Islamic religious education makes students master four core competencies that are in accordance with Islamic Religious Education. Religious education itself will always be assessed in every learning, both direct and indirect learning in all subjects. Religious education has core competence in spiritual attitude, namely living and practicing the teachings of the religion it adheres. ${ }^{6}$

The role of religion, community norms, culture, and customs that are in line with the values of national identity, in this case, must be put forward. As it is known, that Islamic religious education is education that provides knowledge

${ }^{6}$ Rusli, Rusli. (2009). Gagasan Khaled Abu Fadl tentang "Islam Moderat" versus "Islam Puritan" (Perspektif Sosiologi Pengetahuan). Jurnal Ilmiah Ilmu Ushuluddin, 8(1), 99-123.

e-ISSN: 2715-4572

p-ISSN: 2716-1439 
and shapes students' attitudes, personalities, and skills in practicing their religious teachings, which is carried out at least through subjects or lectures at all paths, levels, and types of education.

Given the importance of character in building substantial human resources (HR), it is necessary to carry out character education properly. Furthermore, in this case, educational institutions, especially schools, are seen as strategic places to shape character.

Facing challenges that are coming, the curriculum must be able to equip students with various competencies. The competencies needed in the future in accordance with global developments, including communication skills, ability to think clearly and critically, ability to consider the mental aspects of a problem, ability to be a responsible citizen, ability to try to understand and tolerate different views, ability to live in a globalized society, have a broad interest in life, have a readiness to work, have intelligence with talents or interests, and have a sense of responsibility towards the environment. Achieving these goals requires changes in various other aspects, especially in its implementation in the field. In the learning process, students are "told" to students "find out." In contrast, the assessment process from focusing on knowledge through output assessment becomes ability-based through process assessment, portfolio, and overall and comprehensive assessment of outputs. Therefore, the development of the 2013 curriculum will produce students who are: productive, creative, innovative, effective; through strengthening integrated attitudes, skills, and knowledge.

\section{Literature review}

\subsection{Definition of Islamic Religious Education and Morals}

The Islamic religious education curriculum states that Islamic religious education is a conscious and planned effort in preparing students to recognize, understand, appreciate and believe in the teachings of Islam, piety, and noble character in practicing Islam from the main source of the holy book Al-Qur'an and hadith. ${ }^{7}$ Through the activities of guidance, learning, training, and the use of experience.

Education is a conscious and planned effort to create a learning atmosphere and learning process. Students actively develop their potential to have religious-spiritual strength, selfcontrol, personality, intelligence, noble character, and skills needed by themselves, society, nation, and state.. ${ }^{8}$ Education is the process of changing attitudes and behavior of a person or group of people in an effort to mature humans through teaching and training efforts, processes, actions, ways of educating. ${ }^{9}$ According to Marimba, education is conscious guidance by

${ }^{7}$ Rusli, Rusli. (2020). The Role of Family in Preventing Social Conflict in Society From Islamic Perspectives. HUNAFA: Jurnal Studia Islamika, 17(1), 108-122.

8 UU No. 20 tahun 2003 tentang Sistem Pendidikan Nasional. BAB I, pasal 1. Hasbullah, Dasar-Dasar Pendidikan. (Jakarta:grafindo persada. 2009), hal. 304-305

${ }^{9}$ Kamus Besar Bahasa Indonesia, hal. 204 e-ISSN: $2715-4572$ p-ISSN: 2716-1439 
educators on the physical and spiritual development of students towards the formation of a perfect human being. ${ }^{10}$

Religion is belief and belief in God. Religion regulates human relations with God Almighty, humans with humans, human relations with nature, and human relations with themselves, ensuring harmony, balance, and harmony in human life both as individuals and members of society in achieving outward goals and spiritual happiness.

Meanwhile, Islam is the religion of Allah SWT revealed to the Prophet Muhammad and is a religion that has the core of faith and action (charity). So in the concept of mapping education, religion and Islam aims as a process of transferring knowledge from educators to students to fix morals, morality, and spirituality so that they become adults and are able to distinguish between good and bad so that it is useful for society and the Islamic religion will save in this world and the hereafter.

Textually, Islamic religious education is education based on the normativity of Islamic teachings, which are sourced from the Qur'an and AsSunnah. As for conceptually definitive, Islamic religious education has the understanding as a process of inheritance and development of a human culture that is sourced and guided by Islamic teachings as contained in the Qur'an and described in the Sunnah of the Prophet. Islamic

10 Ahmad Marimba, Pengantar Filsafat Pendidikan Islam, (Bandung : Al-Ma'arif, 1964), hal. 19 religious education is physical and spiritual guidance based on Islamic religious norms towards the formation of the main personality according to Islamic standards. Meanwhile, according to Abdurrahman an-Nahlawi, Islamic religious education is the development of the human mind and the arrangement of behavior and emotions based on Islam, intending to apply the teachings of Islam in the lives of individuals and society, namely in all people's lives.

According to Zakiyah Daradjat: "Islamic religious education is guidance and cares for students so that they can understand the content of Islam as a whole, appreciate the meaning, intent, and purpose of Islam and can practice it and make it a way of life, to bring happiness in the world and the hereafter". ${ }^{11}$

According to Kamal Hasan, who explained education from an Islamic perspective, education is a lifelong process to prepare a person to actualize his role as khalifatullah on earth. With this readiness, it is hoped that it can fully contribute to the reconstruction and development of society in achieving happiness in the world and the hereafter. ${ }^{12}$

While taking into account the several meanings of Islamic religious education mentioned above, it can be understood that Islamic religious education is a conscious effort made by

11 Zakiyah Daradjat, Ilmu Pendidikan Islam (Jakarta: Bumi Aksara, 2011), hal. 86

12 Imas Kurniasih, Mendidik SQ Anak menurut Nabi Muhammad SAW, (Yogyakarta: Pustaka Marwa,2010), hal. 63

e-ISSN: 2715-4572

p-ISSN: 2716-1439 
an educator in preparing and equipping students to recognize, understand, live and believe, fear, and have a noble character in accordance with the teachings of Islam so that they can practice Islamic teachings in daily life, in addition to developing knowledge and technology based on the main sources of Islamic teachings, namely the Qur'an and hadith through learning, guidance, training, instilling values, experience and practice, so that they can shape the character of students.

Islamic religious education in junior high school consists of five aspects which include the Qur'an, faith, morality, fiqh and dates, and Islamic culture. All of these are the unity of Islamic religious education that are interrelated with each other, support each other, fill and complement and have characteristics in themselves.

\subsection{The Purpose of Islamic Religious Education and Morals}

In the Ministerial Regulation (Permen) Number 22 of 2006 concerning Content Standards/Basic Competencies, it is explained that Islamic religious education in junior high schools aims, among others, to develop faith through giving, fertilizing, and developing knowledge, appreciation, practice, habituation and the experience of students about the religion of Islam, so that become a Muslim who continues to develop his faith and piety to Allah SWT. The next goal is to realize Indonesian people who are religious and have a noble character, namely humans who are knowledgeable, diligent in worship, intelligent, productive, honest, fair, ethical, disciplined, tolerant (tasamuh), maintaining personal and social harmony and developing a religious culture in the school community. The main purpose of religious education (Islam) is the students' diversity, not especially the understanding of religion. In other words, what is prioritized by religious education (Islam) is not only knowing (knowing about religious teachings and values) or doing (being able to practice what is known) after being taught in school.

Religious education (Islam) must be oriented more at the level of moral action, namely so that students do not only stop at the level of competence (competence) but to have the will and habits (habit) in realizing the teachings and values of the religion. In daily life. According to Zakiah Daradjat, religious education aims to cover all aspects of humanity, including attitudes, behavior, appearance, habits, and views.13

According to Oemar Hamalik (Umar), said that the implementation of the curriculum includes three main activities, namely program development, learning implementation, and evaluation. Program development includes learning programs, guidance, and counseling or remedial programs. The implementation of learning includes the process of interaction between students and their environment so that changes in behavior occur for the better. While evaluation is an assessment

\section{${ }^{13}$ Zakiah Daradjat, Ilmu Pendidikan}

Islam (Jakarta: Bumi Aksara, 1996), h. 30

e-ISSN: 2715-4572

p-ISSN: 2716-1439 
process carried out throughout the implementation of the curriculum. ${ }^{14}$

Based on the new 2013 curriculum issued by the Ministry of Education and Culture, Islamic religious education in primary and secondary schools is combined with character education, so that the name becomes Islamic religious education. Islamic religious education is taught for 4 hours per week at the elementary school level and 3 hours per week at the secondary school level.

Islamic religious education has the scope of aqidah, morality, worship, and mu'amalah, or it can also be said that Islam regulates the relationship between humans and God (akhlaq bil khaaliq), and humans with fellow humans (Akhlaq bil Mujtama'), even regulates the relationship between humans and the surrounding natural environment (Akhlaq bil Kaun). Akhlaq, which is one of the scopes of Islam, teaches how to behave properly and correctly to anyone according to the holy Qur'an, be it to Allah, to fellow humans, and the natural surroundings.

The general objective of Islamic religious education is to achieve the qualities mentioned in the Qur'an and hadith, while the function of national education is to develop capabilities and shape the character and civilization of a dignified nation in the context of educating the nation's life, aiming to develop the potential of students to become good human beings. have faith and fear of Allah, have a noble character,

\footnotetext{
${ }^{14}$ Umar. (n.d.). Pengembangan Kurikulum
}

Pendidikan Agama Islam Transformatif. 2015.h.34 are healthy, knowledgeable, capable, creative, independent, and become democratic and responsible citizens.

Islamic religious education is tasked with guiding and directing students to become Muslims who believe firmly as a reflection of the faith that has been fostered by the cultivation of religious knowledge, which must be reflected in noble character as the ultimate goal of religious education. The general goal of Islamic education is the realization of a person as a servant of Allah, implied that this goal would realize specific goals. By quoting the letter at-Takwir verse 27 states that that goal is for all humans. So, according to Islam, education must make all humans into human beings who serve themselves to Allah or, in other words, worshiping Allah.

\section{Methodology}

This study uses a qualitative approach ${ }^{15}$ with the object of research is a government junior high school in Palu. In this study, the researchers took one of the government junior high schools to be the case of the study. The case was state senior high school one in a regency Central Sulawesi

We used a qualitative methods in this study wuth several considerations. First, the qualitative methods is helpful when dealing with multiple realities. Second, it can directly present the nature of the relationship between researchers

15 Latepo, Ibrahim, Suharto, Suharto, \& Nurdin, Nurdin. (2021). Understanding Muslim Preaching Students' Use of Social Media. International Journal of International Relations, Media and Mass Communication Studies, 7(1), 5266.

e-ISSN: 2715-4572

p-ISSN: 2716-1439 
and informants ${ }^{16}$. Third, this method is more sensitive and adaptable to the many sharpening of the common direction and the patterns of values encountered. ${ }^{17}$

Data were collected using observation techniques, in-depth interviews with the school principla and teachers from the school, and data were also obtained from written documents. ${ }^{18}$ While the data analysis is done using reduction and verification techniques with various data sources. ${ }^{19}$ The reduced data is then analyzed by claiming to the theoretical concepts used in this study.

\section{Result and Discussion}

\subsection{Islamic Religious Education Learning in Shaping Character}

16. Nurdin, Nurdin. (2021b). Employing Online and Offline Qualitative Interpretive Case Studies in Understanding E-Procurement Effectiveness. International Journal of Quantitative and Qualitative Research Methods, 9(1), 23-41.

17Nurdin, Nurdin. (2018). Institutional Arrangements in E-Government Implementation and Use: A Case Study From Indonesian Local Government. International Journal of Electronic Government Research (IJEGR), 14(2), 44-63. doi: 10.4018/ijegr.2018040104

18. Nurdin, Nurdin, Stockdale, Rosemary, \& Scheepers, Helana. (2013). The Use of Social Media to Gather Qualitative Data: A Case of Government E-Procurement Implementation and Use. Paper presented at the 24th Australasian Conference on Information Systems (ACIS).

19 Nurdin, Nurdin, \& Aratusa, Zana Chobita. (2020). Benchmarking level interactivity of Indonesia government university websites. TELKOMNIKA Telecommunication, Computing, Electronics and Control, 18(2), 853-859.
In an education system, the curriculum is dynamic and must be changed and developed in order to keep up with the developments and challenges of the times. Changes and curriculum development must be carried out systematically and directed. This change must have a clear vision and direction for the national education system with the curriculum change. The 2013 curriculum is a competency-based curriculum (outcomes-based curriculum); therefore, its development is formulated in the Graduate Competency Standards. This is in accordance with the results of an interview with an Islamic religious education teacher who stated that:

The 2013 curriculum is more concerned with implementing an interactive, inspiring, fun, challenging learning process, motivating students to participate actively. The learning process is carried out using a scientific approach (scientific approach) with the process and product-based learning outcomes assessment. $^{20}$

The results of the interview above show that the 2013 curriculum emphasizes interactive and fun learning processes and processes on students, meaning that in the 2013 curriculum, students are required to be more active in learning.

20 Saleh, Guru PAI Government junior high schools , "Wawancara", tanggal 23 Juli 2019, di Ruang Guru. 
In the 2013 curriculum there are core competencies in each subject which include:

Core Competencies:

1. Core Competency-1 (KI-1) for core competencies of spiritual attitudes;

2. Core Competency-2 (KI-2) for the core competence of social attitudes;

3. Core Competency-3 (KI-3) for knowledge competence; and

4. Core Competency-4 (KI-4) for skills competency.

The implementation of the 2013 curriculum is an improvement from the previous curricula. The 2013 curriculum is a follow-up to the competency-based curriculum that was piloted in 2004. The $\mathrm{KBK}$ is used as a reference and guides for the implementation of education to develop various fields of education (knowledge, skills, and attitudes) at all levels and pathways of education, especially in the school path as mandated by Law 20 of 2003 concerning the national education system in the elucidation of article 35, where graduate competence is a graduate's ability qualification which includes attitudes, knowledge, and skills in accordance with agreed national standards.

The 2013 curriculum has fundamental differences in its application, where in the 2013 curriculum, students tend to be more active than teachers. Educational development strategies can be carried out in efforts to improve Islamic religious education through competency-based active student learning, the effectiveness of learning through the curriculum, and increasing the competence and professionalism of teachers, as well as the length of stay in school in the sense of increasing lesson hours.

The competency-based 2013 curriculum focuses on the acquisition of certain competencies by students. Therefore, this curriculum includes a number of competencies and a set of learning objectives that are stated in such a way that Islamic religious education can be observed in the form of student behavior or skills as a criterion of success.

Learning activities need to be directed to help students master at least a minimum level of competence, so that they can achieve the goals that have been set.

The process of implementing character education in Islamic religious education in public junior high schools requires a set of plans and arrangements for content and lesson materials as well as the methods used as guidelines for organizing teaching and learning activities so that the teaching and learning process can run in accordance with the expected goals. In the world of education, this is called the curriculum.

Based on the results of an interview with the Deputy Head of the State Junior High School curriculum regarding the implementation of the 2013 curriculum:

The 2013 curriculum is a curriculum that is structured to shape the character of students. In the concept of the 2013 curriculum, Islamic religious education has a very important role in terms of fulfilling

e-ISSN: $2715-4572$

p-ISSN: 2716-1439 
competence 1 and competence 2, namely the competence of spiritual attitudes and social attitudes. 21

Based on the results of the study, it was found that the implementation of Islamic religious education learning in shaping the character of students through the 2013 curriculum at SMP Negeri 1 Sigi, among others, through the stages of Planning for Islamic Religious Education and character in SMP Negeri in shaping the character of students.

There are plans for character education in learning Islamic religious education and character at Government junior high schools when preparing the lesson plan, namely the syllabus and lesson plans. This character education plan is in accordance with the school guidelines for character education development issued by the Ministry of National Education, namely in planning character education in the subjects included in the syllabus and lesson plans. In making the syllabus and lesson plans, there is one column for the developed value of character education.

Based on the results of interviews with Islamic Religious Education teachers and good manners, it is stated that:

The formation of the character of students begins with planning, including planning for learning Islamic religious education and character in the classroom, before entering the classroom the teacher

${ }^{21}$ Harmawati, Wakases Kurikulum SMP Negeri 1 Sigi, "Wawancara”, tanggal 25 Juli 2019, di ruang wakasek kurikulum. always prepares learning tools to be used when entering the classroom. ${ }^{22}$

The learning process of Islamic religious education subjects is designed in such a way. Each learning activity develops abilities in the cognitive, affective, and psychomotor domains. Therefore, special learning activities are not always needed to develop values in character education. However, developing certain values such as hard work, discipline, honesty, tolerance, independence, love for the homeland, and a love of reading can be made through learning activities that teachers can do in class. The development of several other values such as social care, environmental care, curiosity, and creativity requires conditioning efforts so that students can bring up behaviors that show these values.

\subsection{Stages of Implementation of Learning Islamic religious education and character.}

Based on the previous explanation that the implementation of character education in Islamic Religious Education and Character Education at Government junior high schools uses two ways, namely learning and extracurricular activities. According to the Regulation of the Minister of Religion No. 16 of 2010 concerning the Management of Religious Education, the learning process of religious education is carried out through learning and extracurricular

${ }^{22}$ Saleh, Guru PAI Government junior high

schools , “Wawancara”, tanggal 23 Juli 2019, di Ruang Guru.

e-ISSN: 2715-4572

p-ISSN: 2716-1439 
activities (Article 8 paragraph 3 ). This is in accordance with the results of interviews with teachers of Islamic religious education and manners who stated that:

The implementation of character education in Islamic religious education and character education at Government junior high schools is organized in such a way by determining the material to be delivered, then carried out both in class and outside the classroom. In the implementation of character education, Government junior high schools uses an active and childcentered approach to students' learning process, carried out through activities in the classroom, school, and community. ${ }^{23}$

Learning activities are learning activities carried out face-to-face in the classroom and independent activities outside the classroom in accordance with the Content Standards.

Education related to personality or morals cannot be taught only in the form of knowledge, but there is a need for habituation in daily behavior. After being a good role model, the teacher must encourage students to always behave well in everyday life. Therefore, in addition to assessing, the teacher is also a supervisor of students' daily behavior at school, and this is where the importance of support from all parties is because in the habituation method, students are trained to be able to get

\footnotetext{
${ }^{23}$ Saleh, Guru PAI Government junior high schools , “Wawancara”, tanggal 23 Juli 2019, di Ruang Guru.
}

used to behaving well anywhere, anytime, and with anyone.

Teachers who spearhead the success of a lesson must realize that their responsibility for the success of learning Islamic religious education is not only a cognitive order, no less important is how to provide awareness to students that religious education is a necessity so that students have a high awareness to implement religious knowledge gained in everyday life. This is in accordance with the results of an interview with an Islamic religious education teacher who stated that:

To form a good personality, a teacher not only pays attention to the cognitive aspects of knowledge to students, but the most important thing is the implementation of what they get in class that can be used in everyday life. This is where the creativity of an Islamic religious education teacher and character is needed, where Islamic religious education learning should not only be taught in the classroom but how teachers can facilitate religious learning outside the classroom through activities that are religious in nature and create a school environment that is conducive to learning. religious. ${ }^{24}$

Meanwhile, in terms of the content of the implementation of character education in Islamic religious education and character education at government junior high schools, it is in accordance with the guidelines for developing

${ }^{24}$ Anwar, Guru PAI SMP Negeri 1 Sigi, "Wawancara", tanggal 23 Juli 2019, di ruang guru. e-ISSN: 2715-4572 p-ISSN: 2716-1439 
character education as issued by the ministry of national education, namely the implementation of character education in subjects developing religious character values, honesty, tolerance. Discipline, hard work, creativity, independence, democracy, curiosity, national spirit, love for the homeland, respect for achievement, friendly/communicative, love peace, love to read, care for the environment, social care, and responsibility in classroom learning. Character values are adjusted to $\mathrm{KD}$ and indicators. In the implementation of character education, existing activities can be carried out and then strengthened, and can also organize new activities.

Based on the results of the interviews above, researchers can provide examples when teaching the AlQur'an. Students are then invited to read, understand, and practice the contents of the Koran little by little. Another example is when teaching hadith material about cleanliness, and students are invited to practice directly on how to clean the body, take care of the body, clean the surrounding environment. Furthermore, children are invited to always have a healthy and clean lifestyle by explaining the benefits and wisdom of cleanliness and health and mentioning examples of the good consequences of having a healthy and clean pattern and the bad consequences of ignoring a healthy and clean pattern. The use of such a learning model turns out to be quite easy for teachers to motivate students to behave and behave that shows character values according to the theme or material being studied.
Based on the discussion above, it can be understood that from the character values developed by the Ministry of National Education, the implementation of character education in Islamic religious education and character education at Government junior high schools has all been carried out in accordance with KD and material indicators presented by Islamic religious education and character education teachers.

Based on the research findings, researchers can understand that the implementation of the 2013 curriculum at Government junior high schools is good, although it is not perfect and has not achieved the educational goals that are in accordance with the characteristics of the 2013 curriculum.

The change that appears in the learning of Islamic religious education and character in the 2013 curriculum is the increase in lesson hours, which was originally in the Education Unit Level Curriculum (KTSP). The teaching hours for Islamic Religious Education were only 2 hours per week. So, the curriculum has increased to 3 hours per week. This is in accordance with the results of interviews with the Principal who stated that: Based on the research findings, researchers can understand that the implementation of the 2013 curriculum at Government junior high schools is good, although it is not perfect and has not achieved the educational goals that are in accordance with the characteristics of the 2013 curriculum.

The 2013 curriculum for all subjects has additional hours and PAI, which

e-ISSN: $2715-4572$

p-ISSN: 2716-1439 
was originally only 2 hours in 1 week, now it is 3 hours. ${ }^{25}$

The addition of this clock is very helpful for teachers of Islamic religious education and manners in conveying the values that exist in learning Islamic religious education. In addition, the term that was originally in the education unit level curriculum called Islamic religious education in the 2013 curriculum also underwent a transformation into Islamic religious education and character. The 2013 curriculum for all subjects has additional hours and Islamic religious education, which was originally only 2 hours in 1 week, now it is 3 hours.

An educator needs a method in carrying out the teaching and learning process, so that teaching and learning activities run dynamically because a dynamic atmosphere in the teaching and learning process will have a very good impact on students and teachers as educators. The encouragement of achievement with an optimal teaching and learning process, the 2013 curriculum uses a scientific approach, known as the scientific approach.

\subsection{Extra Curricular Activities}

In the implementation of education in Islamic religious education through extracurricular activities, The implementation of extracurricular according to the researcher, is very good for the implementation of character education in Islamic religious education

\footnotetext{
${ }^{25}$ Mas'at, Kepala SMP Negeri 1 Sigi,

“Wawancara”, tanggal 22 Juli 2019, di ruang Kepala Sekolah
}

and character, especially for the cultivation of religious character values, independence, curiosity, love of reading, social care.

Figure 1. Students praying together

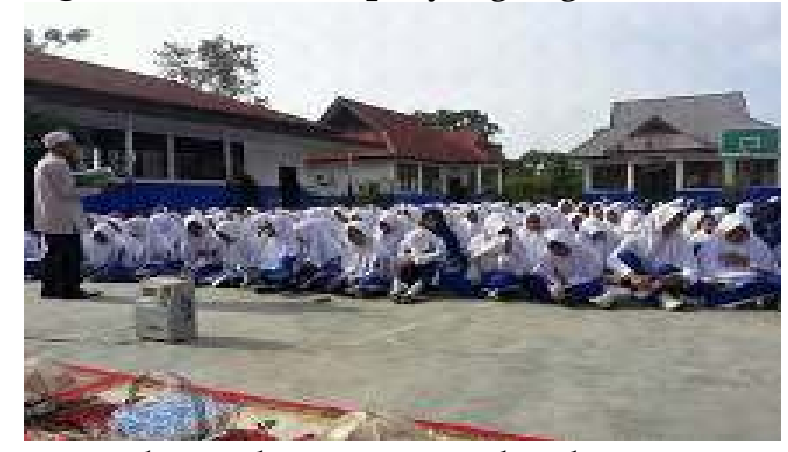

Through various school activities participated in by all students, teachers, principals, and administrative staff at the school, planned from the beginning of the school year, included in the academic calendar and carried out daily as part of the school culture. Examples of activities that can be included in the school program are reading Asma'ul Husa, congregational midday prayers, tahfidz al-Qur'an, and monthly congregational dhikr activities.

Through extracurricular activities and other activities that are participated by all or part of the students, the school is designed from the beginning of the school year and included in the academic calendar. For example, visiting places that foster a sense of love for the homeland, doing community service to foster social care and solidarity (helping those who are stricken by disasters, repairing or cleaning public places, helping clean up places of worship).

Figure 2. Students raising donations e-ISSN: 2715-4572 p-ISSN: 2716-1439 


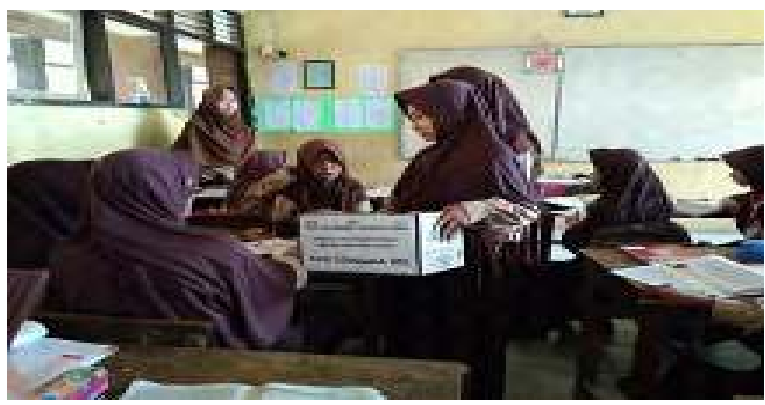

The implementation of character building in Islamic religious education and manners to form the religious character is very appropriate. Students are in an optimal state in carrying out Islamic teachings, namely by praying dzuhur, praying Dhuha Dhikr together. Moreover, in its implementation, students are given the opportunity to manage it. So from here, they have an independent nature. Then for the value of curiosity, students are more flexible in expressing their curiosity by holding mentoring and Islamic discussions. Through this media, the researchers saw that their curiosity would be answered for students who followed, while for senior students, they would know better because they were required to guide their younger siblings.

\subsection{Evaluation of the Implementation of Islamic Religious Education and Morals}

The 2013 curriculum is a curriculum designed to shape the character of students more through the learning process at school. Through this curriculum, it is expected to shape the character of students according to the 18 predetermined characters. For this reason, the next step is to see how far the influence of Islamic religious education and character in shaping the character of students is through learning evaluation.

Evaluation of the implementation of character education in learning Islamic religious education and character in Government junior high schools researchers refers to the theory of Bridgman \& Davis (2000: 130), namely: input (input), process (process), output (result), and outcomes (impact).

First, the input aspect, both students and teachers, the implementation of character education is good. To be able to enter government junior high schools, you must follow several stages, namely administration, tests, and interviews. In addition, these students are fully supported by their parents, who send them to government junior high schools. The work programs of government junior high schools, including character education, are fully supported by parents.

This is in accordance with the results of interviews with Wakakurikulum saying that:

To enter government junior high schools students must go through a series of stages, including file selection, tests and interviews. This activity is expected to get students who have good character. ${ }^{26}$

Based on the results of the interview above, it can be understood that to enroll at government junior high schools, students must follow several stages of selection held by the school. The goal is to find students who have

${ }^{26}$ Harmawati, Wakases Kurikulum SMP Negeri 1 Sigi, "Wawancara", tanggal 25 Juli 2019, di ruang wakasek kurikulum. 
the talent and ability to be further developed in the future.

Then the input of Islamic religious education educators and character is very good. This is because the educational qualifications of educators are in accordance with the Law on Teachers and Lecturers, requiring a minimum of S1. The teachers of Islamic religious education and character at Government junior high schools are all undergraduate graduates from the Islamic religious education program. Then from example, Islamic religious education teachers at Government junior high schools can be a good example for students.

Educators and staff at Government junior high schools have at least a bachelor's degree in education, and some have a master's degree, including teachers of Islamic religious education and character education. The educational qualifications of teachers or educators are very important in an institution such as a school, with a background of knowledge under their control that will provide professional and adequate services to students so that they can develop the character of students in a better direction.

Second, the process. The process of implementing character education in Islamic religious education and character education at Government junior high schools begins with learning planning, namely by compiling a syllabus and lesson plan. After planning, it is continued with the implementation of character education in Islamic religious education. In the process of implementing character education in
Islamic religious education, there are two ways, namely intracurricular and extracurricular. According to the researcher, the process of implementing character education in Islamic religious education and character education at Government junior high schools has been going well. This can be seen from the results of the process of learning Islamic religious education subjects and manners, which are quite satisfactory.

The process of implementing character building in Islamic Religious Education and Character Education at Government junior high schools begins with learning planning, namely by compiling a syllabus and lesson plan. After planning, it is continued with the implementation of character education in Islamic religious education. In the process of implementing character education in Islamic religious education, there are two ways, namely intracurricular and extracurricular. According to the researcher, the process of character building in Islamic religious education and character at government junior high schools, borrowing Thomas Lickona's term, character education contains three components, namely moral knowing, moral feeling, and moral action. The moral feeling aspect is instilled through learning in the classroom, while the moral feeling and moral action are instilled in the classroom and outside the classroom. Of the three components, according to the researcher, the moral aspect of action 
must be carried out continuously through daily habituation. ${ }^{27}$

The problem is that learning Islamic religious education and manners at Government junior high schools is only 3 hours face-to-face a week. As a result, in learning Islamic religious education, children can be conditioned, but when dealing with other teachers or community conditions that are different from learning Islamic religious education and character, children's attitudes can change. ${ }^{28}$ Therefore, according to the researcher, collaboration with all subjects is a must. Actually, there is no problem with other subject teachers because character education at Government junior high schools is already integrated.

The results of the implementation of character education in Islamic religious education and character are good. This can be seen in terms of the value of the subject, both in understanding the material and in attitudes. The results of the researcher's search for Islamic religious education teachers at government junior high schools, the average score was 90, and his attitude got an A predicate.

27 Handayani, Andi Muthia Sari, \& Nurdin, Nurdin. (2021). Understanding Women's Psychological Well-Being in PostNatural Disaster Recovery. Medico Legal Update, 21(3), 151-161.

${ }^{28}$ Latepo, Ibrahim, Suharto, Suharto, \& Nurdin, Nurdin. (2021). Understanding Muslim Preaching Students' Use of Social Media. International Journal of International Relations, Media and Mass Communication Studies, 7(1), 52-66.
In the process and results of the evaluation of character formation that has been carried out by teachers of Islamic religious education and character education at government junior high schools, it has been carried out well. This can be seen from the eighteen character values proclaimed by the ministry of education, which have generally been implemented, although not comprehensively.

\section{Conclusion}

The implementation of Islamic education learning and character shaping of students through the 2013 curriculum at Government junior high schools is carried out in several stages. Namely, the planning stages of Islamic religious education learning which has a few stages like the implementation of Islamic religious education learning and the stages of evaluating Islamic religious education learning at government junior high schools. The planning stage of learning Islamic religious education and character at Government junior high schools were done by making a learning implementation plan (RPP) and syllabus for Islamic religious education subjects. Then in the stages of implementing Islamic religious education and character education at government junior high schools, it is carried out by learning in the classroom and extracurricular activities or activities outside the classroom. Then in the learning evaluation stage, it is carried out through the stages of input, process, output (results), and outcomes (impact). 
Characters that can be formed through learning Islamic religious education and character in the 2013 curriculum at Government junior high schools are the implementation of character education in learning Islamic religious education and character in Government junior high schools above, 18 characters that must be formed in the school environment according to with the mandate of the 2013 curriculum that all characters can be formed in Islamic religious education, this is in accordance with the observations of researchers that all 18 characters that must be formed appear in Islamic religious education subjects. Students' character can be formed not only in the classroom but also outside the classroom.

\section{REFERENCES}

Abdul, Majid \& Dian Andayani. Pendidikan Karakter Perspektif Islam. Bandung: PT. Remaja Rosdakarya, 2012.

Amiruddin, Amiruddin, Nurdin, Nurdin, \& Ali, Moh. (2021). Islamic Education Teacher Communication Strategy in Increasing Students' Learning Interest. International Journal of Contemporary Islamic Education, 3(1), 41-61.

Arifin. Penelitian Kualitatif dalam Ilmuilmu Sosial dan Keagamaan. Malang: Kalimasada Press, 2010.

Askar, Askar, Adawiyah, Adawiyah, \& Nurdin, Nurdin. (2021). Understanding Students' Psychological Distress Complaints through Online
Academic Advising Support. Medico Legal Update, 21(3), 162167.

Burhan Bungin. Analisis Data Penelitian Kuantitatif. cet.2 Jakarta : Raja Grafindo. 2003.

Daradjat Zakiah, Ilmu Pendidikan Islam. Jakarta: Bumi Aksara.1996.

Donal Ari,et al, introductioan to research, diterjemahkan oleh Arief Rahman, Pengantar Penelitian dan Pendidikan. surabaya: Usaha Nasonal.2014.

Fitri Agus Zaenul. Reinventing Human Character (Pendidikan Karakter Berbasis Nilai \& Etika di Sekolah), 2012.

Kusuma Dharma, dkk, Pendidikan karakter . Bandung: Remaja Rosdakarya. 2011.

Handayani, Andi Muthia Sari, \& Nurdin, Nurdin. (2021). Understanding Women's Psychological Well-Being in PostNatural Disaster Recovery. Medico Legal Update, 21(3), 151161.

Husein Umar. Metode Penelitian untuk Skripsi dan Tasir Bisnis. Cet. IV; Jakarta: PT. Raja Grafindo. 2010.

Ida Zusnani, Manajemen Pendidikan Berbasis Karakter Bangsa. 2012

Iskandar. Metodologi Penelitian Pendidikan dan Sosial. Jakarta: Ikapi, 2013.

Kementerian Pendidikan Nasional, Pedoman Pelaksanaan Pendidikan karakter. Jakarta: Pusat Kurikulum dan pembukuan Badan Penelitian dan Pengembangan Kementerian Pendidikan Nasional. 2011.

Latepo, Ibrahim, Suharto, Suharto, \& Nurdin, Nurdin. (2021). Understanding Muslim Preaching e-ISSN: 2715-4572 p-ISSN: 2716-1439 
Students' Use of Social Media. International Journal of International Relations, Media and Mass Communication Studies, 7(1), 52-66.

Lexy J. Moleong, Metodologi Penelitian Kualitatif. Cet. XVII; Bandung: PT. Remaja Rosdakarya, 2002.

Mahmud. Metode Penelitian Pendidikan. Bandung: Pustaka Setia, 2011.

Matthew B. Milles dan A. Michael Huberman, Qualitative Data Analisis, diterjemahkan oleh Tjecep Rohendi Rohili dengan judul Analisis Data Kualitatif: Buku tentang Metode-metode Baru. Cet. I; Jakarta: UI Pres,2005.

Moh. Said. Pendidikan Karakter di Sekolah. Surabaya: Jaring Pena. 2011.

Nurdin, Nurdin. (2021b). Employing Online and Offline Qualitative Interpretive Case Studies in Understanding E-Procurement Effectiveness. International Journal of Quantitative and Qualitative Research Methods, 9(1), 23-41.

Nurdin, Nurdin. (2018). Institutional Arrangements in E-Government Implementation and Use: A Case Study From Indonesian Local Government. International Journal of Electronic Government Research (IJEGR), 14(2), 44-63. doi: 10.4018/ijegr.2018040104

Nurdin, Nurdin, Stockdale, Rosemary, \& Scheepers, Helana. (2013). The Use of Social Media to Gather Qualitative Data: A Case of Government EProcurement Implementation and Use. Paper presented at the 24th Australasian Conference on Information Systems (ACIS).
Nurdin, Nurdin, \& Aratusa, Zana Chobita. (2020). Benchmarking level interactivity of Indonesia government university websites. TELKOMNIKA Telecommunication, Computing, Electronics and Control, 18(2), 853-859.

Ruslan, Rosady. Metode Penelitian Public Relation dan Komunikasi. Cet. IV; Jakarta: PT. Raja Grafindo Persada. 2004.

Rusli, Rusli, \& Nurdin, Nurdin. (2021). Understanding Indonesia millennia Ulama online knowledge acquisition and use in daily fatwa making habits. Education and Information Technologies. doi: 10.1007/s10639021-10779-7

Rusli, Rusli. (2014). Teaching Usul alFiqh: A Multicultural Education Model. Al-Tahrir: Jurnal Pemikiran Islam, 14(2), 447-464.

Rusli, Rusli. (2009). Gagasan Khaled Abu Fadl tentang "Islam Moderat" versus "Islam Puritan" (Perspektif Sosiologi Pengetahuan). Jurnal Ilmiah Ilmu Ushuluddin, 8(1), 99-123.

Rusli, Rusli. (2020). The Role of Family in Preventing Social Conflict in Society From Islamic Perspectives. HUNAFA: Jurnal Studia Islamika, 17(1), 108-122.

Sugiyono. Metode Penelitian Pendidikan Pendekatan Kuantitatif, Kualitatif, dan RED, 1994.

Umar. Pengembangan Kurikulum Pendidikan Agama Islam Transformatif. Yogyakarta. 2016 
International Journal of Contemporary Islamic Education

Vol. 3 No. 2 Tahun 2021

Wibowo, Agus. Manajemen Pendidikan

Karakter di Sekolah. Yokyakarta :

Pustaka Pelajar 2013.

Winarno Surakhmad. Dasar dan Teknik Research. Pengentar Metodologi

Ilmiah. Bandung: Torsito, 2000.

e-ISSN: 2715-4572

p-ISSN: 2716-1439 